\title{
Paradygmatyczne punkty widzenia nauk o bezpieczeństwie
}

\section{Paradigmatic Points of View of Security Sciences}

\section{- Abstrakt •}

Koncepcja paradygmatu stworzona przez Th.S. Kuhna odwołuje się do odróżnienia nauki dojrzałej od nauki przedparadygmatycznej. W stadium tej ostatniej mogą konkurować różne podejścia. W naukach o bezpieczeństwie trwa dyskusja nad poszukiwaniem paradygmatów, która z jednej strony może oznaczać konsensus poglądów w ramach jednej dyscypliny lub założeń przeciwstawnych. Dyskusja jest konsekwencją ewolucji tej stosunkowo niedawno wyodrębnionej dyscypliny i prowadzi do określenia jej specyfiki. W pracy przedstawiono różne ujęcia paradygmatu zaproponowane przez przedstawicieli zajmujących się badaniem szeroko pojętego bezpieczeństwa, które prowadzą do wieloparadygmatowości. Problemem badawczym jest próba odpowiedzi na pytanie, czy przedstawiane punkty widzenia stanowia podstawy do sformułowania spójnych założeń paradygmatów na gruncie nauk o bezpieczeństwie i jakie uczeni proponują paradygmaty $\mathrm{w}$ tej dyscyplinie naukowej. Ustabilizowanie jednego wspólnego podejścia, jako najbardziej efektywnego, oznaczać będzie ukształtowanie się paradygmatu nauk o bezpieczeństwie. $\mathrm{Na}$ zakończenie zaproponowano koncepcję bezpieczeństwa personalnego ujętą w paradygmat systemowy.

\section{- Abstract •}

Kuhn's concept of paradigm refers to the distinction between mature and pre-paradigmatic science. Different approaches may compete in the latter stage. In security sciences, there is a discussion on the search for paradigms, which can mean a consensus of views within one discipline or contradictory assumptions. The discussion is a consequence of the evolution of this relatively recently emerged discipline and leads to the definition of its specificity. The paper presents various approaches to the paradigm proposed by representatives of security research in the broad sense of the term, which lead to a multi-paradigm shift. The research problem is an attempt to answer the question whether the presented points of view are the basis for formulating coherent assumptions of paradigms on the grounds of safety sciences and which scientists propose paradigms in this scientific discipline. Establishing one common approach as the most effective one will mean that a paradigm of safety science will emerge. Finally, the concept of personal security was proposed in terms of the system paradigm. 
Słowa kluczowe: paradygmat; nauki o bezpieczeństwie; model bezpieczeństwa personalnego
Keywords: paradigm; security studies; personal security model

\section{Wstęp}

Rozważania o paradygmacie należą obecnie do interesującego obszaru zainteresowań nauk o bezpieczeństwie. Oznaczają one poszukiwanie wzoru czy modelu przedmiotu badań dla tej dyscypliny naukowej. Analiza literatury przedmiotu wskazuje, że konteksty widzenia paradygmatu mogą wskazywać na krzyżowanie się różnych intencji. $Z$ jednej strony mogą wyjaśniać i wzmacniać naukowo przedmiot formalny i materialny nauk o bezpieczeństwie. $Z$ drugiej zaś strony mogą wskazywać na permanentną ewolucję pojęcia bezpieczeństwa badaną z perspektywy różnych dyscyplin naukowych.

Pojęcie paradygmatu można odnaleźć w Powszechnej encyklopedii filozofii, która definiuje go następująco: „(gr. parádeigma - wzór, model; łac. paradigma - wzór, przykład) - pierwotne określenie idei platońskiej, która stanowiła prawzór rzeczy zmiennych; współcześnie: w językoznawstwie - zespół form deklinacyjnych albo koniugacyjnych właściwych danemu rodzajowi wyrazów; w retoryce - wyjątkowo jasny i typowy przykład ilustrujący omawianą kwestię" (Powszechna encyklopedia filozofi, 2007). Takie rozumienie paradygmatu dla Thomasa S. Kuhna okazało się zbyt wąskie, określił go zatem jako zbiór pojęć i teorii definiujących podstawy danej dyscypliny naukowej w określonym czasie. Uważał, że paradygmaty to „powszechnie uznawane osiągnięcia naukowe, które w pewnym czasie dostarczają społeczności uczonych modelów problemów i rozwiązań” (Kuhn, 2001). Jako naukowy punkt widzenia są sposobem stawiania i rozwiązywania problemów w szkołach naukowych.

Koncepcja paradygmatu Th. Kuhna odwołuje się do odróżnienia nauki dojrzałej od pierwotnego stadium rozwojowego określonego mianem nauki przedparadygmatycznej. W tym stadium mogą konkurować ze sobą różne punkty widzenia. Ustabilizowanie jednego jako najbardziej uznanego przez środowisko naukowe oznaczać będzie ukształtowanie się paradygmatu nauk o bezpieczeństwie. Natomiast wielość punktów widzenia (koncepcji) może być postrzegana jako stan przejściowy (przedparadygmatyczny) lub jako stan trwały, dowodzący, że pojęcie paradygmatu nie może być właściwie zastosowane do tej dziedziny poznania.

Thomas S. Kuhn podkreślił niewspółmierność oraz konkurencję, a nawet walkę paradygmatów, która prowadzi do rewolucji naukowych, zmieniających domi- 
nujący paradygmat. Większość badaczy reprezentujących nauki o bezpieczeństwie przyjmuje, że tę dyscyplinę da się wpisać w koncepcję paradygmatu. Można jednak przyjąć, że ze względu na stan ich rozwoju przeżywają okres przedparadygmatyczny. Prostą odpowiedzią na pytanie o przedmiot badań nauk o bezpieczeństwie powinno być bezpieczeństwo. Jednak na posiedzeniu sekcji nauk humanistycznych i społecznych Centralnej Komisji do spraw Stopni i Tytułów, konstytuującym formalnie nauki o bezpieczeństwie, przyjęto, że są to współczesne systemy bezpieczeństwa w wymiarze militarnym i niemilitarnym oraz ich funkcjonowanie na różnych poziomach organizacyjnych (Glen, 2014). Pojęcie bezpieczeństwa zawiera w sobie paradygmat relatywistyczny, który nie uznaje wartości uniwersalnych (Wróblewski, 2017), oraz presumpcje wartościujące, charakterystyczne dla obszaru nauk społecznych i humanistycznych, a obce naukom przyrodniczym.

Bezpieczeństwo nie jest pojęciem jednorodnym, a w jego skład wchodzi wiele mniejszych składników „przydawkowych” takich jak np. bezpieczeństwo społeczne, polityczne itd. Zakres, który obejmuje, z pewnością nie ułatwia wyodrębnienia paradygmatu wiodącego. Pewne paradygmaty (zwłaszcza Burrella i Morgana) pretendują według niektórych naukowców do roli obowiązujących w naukach o bezpieczeństwie.

\section{„Ferment” w naukach o bezpieczeństwie}

W koncepcji Th. Kuhna paradygmat jest przede wszystkim sposobem wyjaśnienia rewolucyjnej zmiany w nauce. „W trakcie rewolucji naukowej zmieniają się [...] problemy uważane za ważne, a nawet za sensowne, kryteria oceniania ich proponowanych rozwiązań, sposoby, na jakie naukowcy spostrzegają świat wokół siebie, a także język, jakiego używają do opisu zjawisk - a nie jest możliwe przetłumaczenie opisów dokonanych w nowym języku na języki używane wcześniej i na odwrót. A przede wszystkim zmieniają się [...] czynne założenia stylu myślowego" (Sady, 2015). To stwierdzenie jest również istotne, mając na uwadze tryb wyodrębnienia się dyscypliny nauk o bezpieczeństwie, która konstruuje swój przedmiot poznania.

Nie dziwi więc fakt, że wielu autorów wskazuje na brak w naukach o bezpieczeństwie powszechnie przyjętego paradygmatu i zauważa, że nauki te znajdują się w przedparadygmatycznym stadium rozwoju (Zięba, 2012; Korzeniowski, 2012). Przyjęcie jednego paradygmatu w naukach o bezpieczeństwie przesądziłoby o dominującej perspektywie badania bezpieczeństwa w tej dyscyplinie naukowej. Należy podkreślić, że bezpieczeństwo ze względu na swoją wielowymiarowość wy- 
maga badań inter- czy transdyscyplinarnych, dlatego też konieczne jest przekraczanie granic pomiędzy poszczególnymi dziedzinami i dyscyplinami naukowymi, a także wykorzystywanie dorobku teoretycznego i warsztatu metodologicznego różnych nauk, takich jak: filozofia, historia, socjologia, psychologia, pedagogika, nauki ekonomiczne, nauki o zarządzaniu, nauki prawne i polityczne, nauki wojskowe, medyczne i przyrodnicze (Hołyst, 2014). Podejście transdyscyplinarne to generalna zasada epistemologiczno-metodologiczna nauk o bezpieczeństwie (Kitler, 2015). Tworząc paradygmat nauk o bezpieczeństwie, trzeba więc „pokonać” teoretyczną niewspółmierność oraz dokonać syntezy różnych nauk. Można się też zastanowić, w jaki sposób wyodrębnienie nauk o bezpieczeństwie przyniosło zmianę i postęp w badaniach bezpieczeństwa. To pytanie odnosi się w dużej mierze do ontologii badań bezpieczeństwa, a w szczególności do odpowiedzi na pytanie, co jest przedmiotem jej poznania i czy spełnia wymagania stawiane dyscyplinie naukowej (ryc. 1).

Ryc. 1. Wymagania stawiane naukom o bezpieczeństwie (dyscyplinie naukowej)

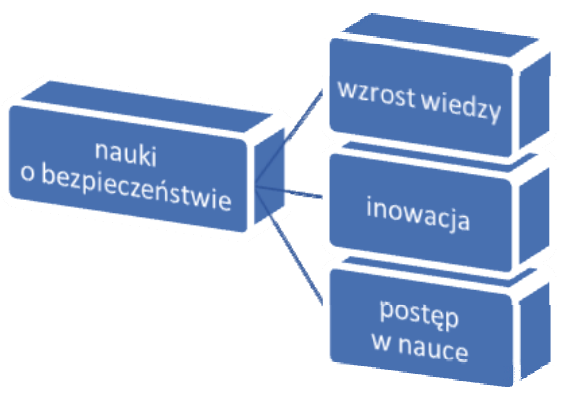

Źródło: opracowanie własne.

Określoną dziedzinę wiedzy można nazywać nauką wtedy, gdy posiada naukową metodologię (Frankfort-Nachmias, Nachmias, 2001) Szczegółowe dyscypliny definiują po swojemu aparat pojęciowy, wprowadzając odmienne metody lub „dopasowując” je z innych dyscyplin. Pozytywnym efektem powinien być wzrost wiedzy i postęp w nauce. Nie mogą więc dziwić próby sformułowania założeń dotyczących specyfiki poznawanego przedmiotu i określenia dominującego paradygmatu.

Początek badania „bezpieczeństwa” wyszedł z założeń innych dyscyplin naukowych. Zakłada też obecność, wbrew intencjom Th. Kuhna, wielu paradygmatów. 
Zasadne wydaje się dokonanie wyboru między nimi lub uznanie wieloparadygmatowości nauk o bezpieczeństwie. To ostatnie ujęcie pozwala zauważyć konkretne związki pomiędzy różnymi dyscyplinami nauk, a także stwarza podstawy do poszukiwań interdyscyplinarnego czy transdyscyplinarnego paradygmatu fenomenu bezpieczeństwa.

Można wyjść z założenia, że ewolucja paradygmatu bezpieczeństwa wiąże się z przejściem od paradygmatu „bezpieczeństwa narodowego” (opartego na realizmie), przez „bezpieczeństwo międzynarodowe” (związane z idealizmem czy liberalizmem), paradygmatem „bezpieczeństwa globalnego” (opartego na konstruktywizmie) do paradygmatu bezpieczeństwa personalnego uwzględniającego wieloparadygmatowość nauk o bezpieczeństwie.

I tak Ladislav Hofreiter wymienia trzy bazowe obszary nauk, na których dokonywany jest, jego zdaniem, „szczep” nauk o bezpieczeństwie, tj. nauki: społeczne, przyrodnicze oraz techniczne (Hofreiter, 2012). Wyróżnił trzy paradygmaty badań nad bezpieczeństwem: paradygmat państwocentryczny, koncentrujący się na obronie kraju przed zagrożeniami militarnymi i niemilitarnymi, paradygmat ludzkocentryczny (personalny), skoncentrowany na bezpieczeństwie pojedynczych ludzi, i paradygmat securitologiczny, ujmujący bezpieczeństwo jako zjawisko dynamiczne, wszechstronne, wieloczęściowe o pionowej i poziomej strukturze (Hofreiter, 2013). Securitologia jest uznawana za naukę praktyczną, która ukazuje perspektywę niwelowania zagrożeń dla istnienia, rozwoju i prawidłowego funkcjonowania człowieka i organizacji. Cechą wyróżniającą tej nauki jest jej eklektyczna podstawa epistemologiczno-metodologiczna, którą charakteryzuje: podejście holistyczne i dialektyczne, stosowanie analizy systemowej, przekraczanie granic pomiędzy dyscyplinami naukowymi, wykorzystywanie warsztatu metodologicznego i dorobku teoretycznego różnych nauk (Korzeniowski, 2007).

Ryszard Zięba paradygmaty dla nauk o bezpieczeństwie wyprowadza z ugruntowanego w stosunkach międzynarodowych podziału. Wskazuje na trzy podstawowe ujęcia bezpieczeństwa, tj. realistyczne, skoncentrowane na bezpieczeństwie państwa i akcentujące czynnik militarny (siły); liberalistyczne, preferujące niemilitarne metody kształtowania bezpieczeństwa i otwarcie się na niepaństwowych uczestników stosunków międzynarodowych; konstruktywistyczne, opierające się na założeniu, że nie istnieje obiektywna rzeczywistość społeczna, która jest konstruktem społecznym, produktem życia społecznego i efektem jego wielokrotnej reinterpretacji (Zięba, 2012).

Dwa pierwsze paradygmaty zakładają, że świat społeczny należy badać tak samo jak świat przyrody. Mieszczą się więc w paradygmacie pozytywistycznym. Zakładają, że bezpieczeństwo jest bytem obiektywnym, istniejącym niezależnie 
od badającego. Składa się ze zjawisk i zdarzeń powiązanych ze sobą przyczynowo-skutkowo. Zakłada, że wiedzę o bezpieczeństwie należy opierać w głównej mierze na obserwacji. Konstruktywizm natomiast należy do ujęć postpozytywistycznych. Zakłada on, że świat społeczny jest światem kultury, a tym samym wartości. Badając fenomen bezpieczeństwa, nie można się pozbyć subiektywności. Jan Czaja zauważył, że „Bezpieczeństwo kulturowe jest wymiarem, jakże często niedocenianego, bezpieczeństwa ludzkiego. Składa się z bezpieczeństwa jednostkowego oraz poczucia zbiorowej tożsamości, które są tak charakterystyczne dla naszego postmodernistycznego świata. Zawiera - choć się do tych aspektów nie ogranicza - wolność myśli, sumienia, mowy, stylu życia, przynależności etnicznej, płci, poczucia przynależności do stowarzyszeń, związków, obejmuje także kulturalne i polityczne współzawodnictwo" (Czaja, 2008).

W tym miejscu rozważań można przypomnieć, że każdy paradygmat naukowy składa się z dwóch rodzajów założeń filozoficznych: ontologicznych i epistemologicznych. Pierwsze odnoszą się do pytań o charakter bytu i naturę rzeczy, o to, czym jest bezpieczeństwo i kogo dotyczy. Drugie założenia dotyczą pytań o poznanie naukowe, o możliwości i zasięg ludzkiego poznania fenomenu bezpieczeństwa. Do tego dochodzi wybrana przez badacza metodologia oraz cel badań, sposób gromadzenia wiedzy oraz interpretacja wyników. Określając kierunki badań naukowych „bezpieczeństwa”, należy też uwzględnić system wartości, a więc związek z kontekstem kulturowym. Ryszard Wróblewski wymienia dodatkowo siatkę pojęciową oraz założenia prakseologiczne (Wróblewski, 2017).

Krzysztof Drabik podkreślił współzależność kultury i bezpieczeństwa: „Dążenie do zapewnienia bezpieczeństwa personalnego jest wyrazem ogólnych i uniwersalnych tendencji kulturowych. Potwierdza się zatem konstatacja, iż kształtowanie bezpieczeństwa jest elementem kultury” (Drabik, 2013). Waldemar Kitler słusznie zauważył, że „wielu teoretyków, jak i praktyków zajmujących się problematyką szeroko pojętego bezpieczeństwa wprowadziło do wiedzy naukowej i działalności praktycznej wiele różnych ich zastosowań, nie zachowując niezbędnej dyscypliny definicyjnej" (Kitler, 2011). Dlatego zrozumienie istoty bezpieczeństwa być może nie polega na przyjęciu jednej powszechnie uznawanej definicji bezpieczeństwa, ale na określeniu właściwych paradygmatów. 
Ryc. 2. Bezpieczeństwo w pryzmacie „trzech podmiotów bezpieczeństwa”

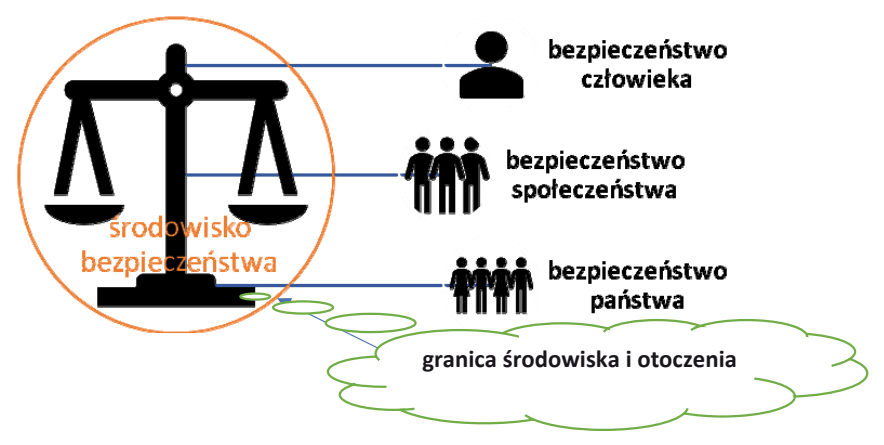

Źródło: opracowanie własne.

Klasyfikacja paradygmatów może się opierać na nastawieniu na jednostkę społeczeństwo lub państwo (ryc. 2) lub na kryterium subiektywnym i obiektywnym.

Dążąc do określenia paradygmatu bezpieczeństwa, w pierwszej kolejności należy odnieść się do części składowych bezpieczeństwa, tj. podmiotu, przedmiotu, środowiska oraz otoczenia. Analiza literatury wskazuje, że mamy do czynienia z licznymi dyskusjami na temat tożsamości nauk o bezpieczeństwie, podmiocie i przedmiocie badań (Kośmider, Kitler, 2017; Piwowarski, Gierszewski, 2018; Jurgilewicz, Sulowski, 2018).

Bezpieczeństwo przez długi czas rozpatrywane było w kontekście strukturalnym, głównie od strony instytucjonalnej i organizacyjnej państwa, którego zadaniem była i jest ochrona i obrona podmiotów bezpieczeństwa. Rzadziej, w analizach z zakresu bezpieczeństwa, głównym punktem odniesienia była osoba ludzka, czyli bezpieczeństwo personalne (Kołodziejczyk, 2009).

Bezpieczeństwo w pryzmacie „trzech podmiotów bezpieczeństwa” wskazuje, że perspektywa bezpieczeństwa państwa nie jest jedynym obszarem analiz (ryc. 2). Obecnie brakuje sprecyzowanego, powszechnie przyjętego sposobu widzenia bezpieczeństwa, co utrudnia budowanie tożsamości nauk o bezpieczeństwie (Gierszewski, 2017).

Można w uproszczeniu powiedzieć, że paradygmat w naukach o bezpieczeństwie jest sposobem widzenia bezpieczeństwa. Dlatego może warto wrócić do koncepcji Th. Kuhna i wskazać, co powinien określać paradygmat nauk o bezpieczeństwie. 
Ryc. 3. Cechy paradygmatu w naukach o bezpieczeństwie (dyscyplinie naukowej)

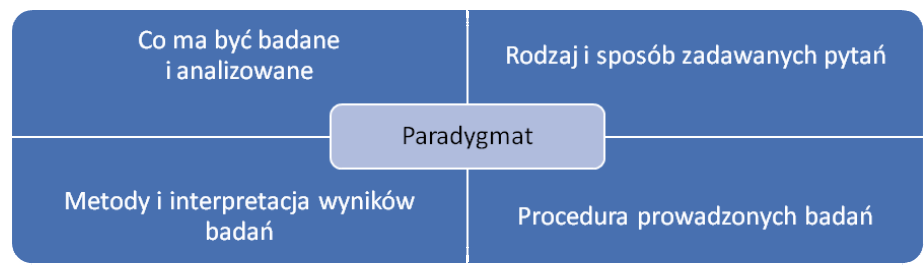

Źródło: opracowanie własne z inspiracji Th. Kuhna (2011).

Thomas S. Kuhn stworzył podstawy do określania m.in. zakresu badań i analiz, sposobu stawiania problemów oraz interpretowania odpowiedzi, a także rodzaju narzędzi badawczych stosowanych w danej nauce (ryc. 3).

Andrzej Glen uważa, że właściwym podejściem w poszukiwaniu paradygmatu adekwatnego do potrzeb nauk o bezpieczeństwie staje się komplementarne wykorzystywanie $\mathrm{w}$ poznaniu bezpieczeństwa czterech paradygmatów sklasyfikowane wg Gibsona Burrella i Garetha Morgana, tj. funkcjonalizmu, radykalnego strukturalizmu, interpretatywizmu oraz radykalnego humanizmu (Glen, 2014). Argumentem uzasadniającym przyjęcie takiego rozwiązania jest podmiotowe traktowanie człowieka, jego praw i wolności. Klasyfikacja ta jest wypadkową obiektywnej i subiektywnej epistemologii badanych zjawisk. Epistemologia obiektywna związana jest z ontologią realizmu i determinizmu, które głoszą, że badana rzeczywistość jest niezależna od „ludzkiego umysłu”. W subiektywizm wpisany jest natomiast nominalizm i woluntaryzm, według których rzeczywistość nie istnieje realnie i niezależnie od ludzkiego umysłu. Wpisuje się to w istotę bezpieczeństwa, którą wiąże się z kategoriami obiektywnymi i subiektywnymi. Często w literaturze podkreśla się, że zagrożenie istotnych dla danego podmiotu wartości (zaliczanych do jego bezpieczeństwa) może być postrzegane subiektywnie (a więc zależnie od percepcji podmiotu postrzegającego) lub/i obiektywnie (jako rzeczywiste; Zięba, 2012). Wymieniony wyżej radykalny humanizm i interpretatywizm można powiązać z postrzeganiem subiektywnym, a radykalny strukturalizmu i funkcjonalizm z wymiarem obiektywnym.

Funkcjonalizm zakłada koncentrowanie się na problemie bezpieczeństwa (jako potrzebie wspólnej) i przezwyciężaniu różnorodnych konfliktów, opierając się na idei współpracy. Stawia za wzór dążenie do utrzymania stanu równowagi pomiędzy podmiotami bezpieczeństwa w procesie wymiany (regulacja). Postuluje więc obiektywizm i technikę ankietową w metodzie sondażu diagnostycznego. 
Paradygmat radykalnego strukturalizmu opiera się na założeniu istnienia obiektywnej rzeczywistości społecznej, która wymaga przebudowy (zmiany). Problematyka badań bezpieczeństwa powinna obejmować mechanizmy bliskie naukom przyrodniczym, a dotyczące: władzy, instrumentalizmu czy dominacji. Badacze wykorzystują tu techniki metody sondażu diagnostycznego, takie jak: wywiady pogłębione, obserwacje oraz analizy dyskursu czy analizy porównawcze.

Paradygmat interpretatywny koncentruje się na opisaniu współzależności w złożonych strukturach społecznych i organizacjach. Kluczem do tworzenia teorii naukowej jest uchwycenie i zrozumienie sensu bezpieczeństwa z punktu widzenia zaangażowanego obserwatora. W metodyce badań dominować więc będą badania terenowe i analizy tekstów. Przeprowadzane będą wywiady pogłębione, studia przypadku, obserwacje i krytyczna analiza tekstów. Rezultatem badań nie jest kwantyfikacja, ale zrozumienie.

Paradygmat radykalnego humanizmu wydaje się najbliższy postmodernizmowi. Jest to najmniej jednorodne podejście poznawcze ze wszystkich paradygmatów. Charakteryzuje się: subiektywizmem, relatywizmem poznawczym, naukową niespójnością (Sułkowski, 2012).

Trudnością wydaje się scalenie wiedzy dotyczącej bezpieczeństwa, która rozproszona jest w wielu paradygmatach i podejściach badawczych. Przecież oprócz pretendujących do roli obowiązujących paradygmatów Burrella i Morgana można wymienić też inne, np. Guby i Lincolna (Guba, Lincoln, 1994) czy Ritzera (Gray, 2005). Dla Ryszarda Wróblewskiego w naukach o bezpieczeństwie najbardziej przydatny jest realizm neoklasyczny (Wróblewski, 2017). Trafnie dobrany paradygmat powinien dać przybliżony obraz rzeczywistości (bezpieczeństwa) i wskazać właściwy kierunek zmian w jego poprawie. Dotyczyć powinien ogólnej koncepcji bezpieczeństwa i mechanizmów jego zapewnienia. Mając do dyspozycji opisane wyżej klasyfikacje paradygmatów, można mieć nadzieję, że nie jest to lista zamknięta. Jeżeli bowiem zjawisko bezpieczeństwo jednostki jest widziane jako niezależny od poznania byt realny, to można założyć, że badacz jest w stanie dokonać obiektywnej, zewnętrznej obserwacji. Wybierze wówczas paradygmat pozytywistyczny (względnie postpozytywistyczny) i związane z nim strategie badań ilościowych ocechach wyjaśnień nomotetycznych. Natomiast w sytuacji, gdy bezpieczeństwo traktuje w kategoriach relatywnych pojęć, nieuchwytnych wprost i wymykających się spod wszelkich uogólnień, powinien wybrać paradygmat konstruktywistyczny i związane z nim strategie jakościowe o cechach wyjaśnień idiograficznych. Na paradygmaty powinno się patrzeć z perspektywy użyteczności naukowej eksploracji, czyli celu badań i struktury badanego zjawiska. 
W naukach społecznych pojawiają się nowe paradygmaty. Bezpieczeństwo badane jest obecnie w kategoriach zarówno obiektywnych, jak i subiektywnych, ponieważ nadal funkcjonują zróżnicowane teorie, które te rodzaje epistemologii potwierdzają. Obecnie można zaobserwować zmiany zachodzące w paradygmacie nauki, szczególnie w naukach społecznych, obejmują one zwrot od pojęcia części ku pojęciu całości (systemu). Ta orientacja jest najpowszechniej znana i stosowana. Następuje też zwrot od stosowania pojęć związanych ze strukturą w kierunku badania procesów. W naukach o bezpieczeństwie na popularności zyskuje paradygmat systemowy, który postaram się opisać na podstawie bezpieczeństwa personalnego.

\section{Bezpieczeństwo personalne w paradygmacie systemowym}

W naukach o bezpieczeństwie daje się zauważyć duże zróżnicowanie proponowanych, ale nie wiem czy do końca możliwych do praktycznego stosowania paradygmatów. Można w tym miejscu przyjąć, że żaden nie został do tej pory przyjęty jako dominujący. Brak wyodrębnienia subdyscyplin różniących się metodyką, przedmiotem badań czy podejściem badawczym powoduje, że głównym kryterium doboru paradygmatów są koncepcje ugruntowane w innych naukach społecznych (Gierszewski, 2018). Nie jestem więc do końca przekonany, czy typologię Burrella i Morgana można bezkrytycznie osadzić w praktyce bezpieczeństwa.

Pomijając przytaczane $\mathrm{w}$ literaturze przydawki bezpieczeństwa, proponuję ograniczyć się do dychotomicznego wyróżnienia bezpieczeństwa personalnego i bezpieczeństwa strukturalnego (Świniarski, 1977), które można osadzić w paradygmacie systemowym. Ujęcie systemowe odnosi się do integralnego interpretowania różnych systemów bezpieczeństwa (Gierszewski, 2013). Paradygmat systemowy oznacza zbiór wzajemnie powiązanych i uzupełniających się koncepcji i teorii, który w sposób holistyczny ujmuje rzeczywistość. Łączy się z paradygmatem funkcjonalistycznym przez pojęcie integracji systemowej, rozumianej przede wszystkim w aspekcie spójności funkcjonalnej oraz poprzez dążenie do utrzymania równowagi w systemie (homeostaza). Homeostaza stanowi zdolność systemu do utrzymywania dynamicznej równowagi z jego środowiskiem. Zastosowaniem analizy systemowej w badaniach nad polityką jako pierwszy zajął się David Easton, który wskazał na możliwość analizy procesów zachodzących w państwie przez pryzmat systemu politycznego.

System bezpieczeństwa charakteryzuje się wysokim stopniem złożoności, ponieważ składa się z bardzo różnorodnych elementów powiązanych ze sobą, na które wywierają wpływ liczne zagrożenia. Obiektami bezpieczeństwa są ludzie 
oraz wszystkie systemy, do których przynależą. Bezpieczeństwo personalne, jak wskazuje nazwa, koncentruje się na jednostce ludzkiej. Zakłada uznanie człowieka za byt osobowy, a jego bezpieczeństwo za główną wartość. Ujęcie systemowe pozwala ujawnić różne związki i relacje oraz ukazać nowe konteksty badanego problemu. Jak nakreślono wyżej, konstruowany system bezpieczeństwa odnosi się do konkretnego podmiotu bezpieczeństwa, którego umowna granica oddziela system od otoczenia (ryc. 2). Dlatego szczególnie trudnym zadaniem przy modelowaniu systemu bezpieczeństwa personalnego jest problem jego klasyfikacji.

Budując system bezpieczeństwa człowieka, można zastanowić się, jak właściwie sformułować problem badawczy na gruncie nauk o bezpieczeństwie. R. Wróblewski traktuje nauki o bezpieczeństwie jako nauki o ochronie fundamentalnych wartości człowieka i społeczeństwa państwowego (Wróblewski, 2017). Ponieważ w ogólnej teorii systemów poszczególne zjawiska rozpatruje się jako wzajemnie ze sobą powiązane, a nie jako wzajemnie izolowane elementy systemu, to system może dotyczyć sfery materialnej, fizycznej czy psychicznej, które można wyodrębnić jako podsystemy. Można się zastanowić, jakie elementy są istotne do godnego życia i jak skonstruowany jest system bezpieczeństwa chroniący tę sferę funkcjonowania każdej osoby fizycznej.

Godność człowieka jest współcześnie postrzegana jako wartość centralna w systemach konstytucyjnych jako podstawowe źródło wolności i praw socjalnych. Ochrona godności człowieka znajduje zapis w wielu dokumentach międzynarodowych (np. Powszechna Deklaracja Praw Człowieka w art. 1 głosi: „Wszyscy ludzie rodzą się równi pod względem swej godności i swych praw. Są oni obdarzeni rozumem i sumieniem i winni odnosić się względem siebie w duchu braterstwa") i dokumentach krajowych, a szczególnie w Konstytucji (Dz.U. z 1997 r., Nr 78, poz. 483), która jest gwarantem poszanowania praw i wolności. Można przywołać np. jej art. 30, który stanowi: „Przyrodzona i niezbywalna godność człowieka stanowi źródło wolności i praw człowieka i obywatela. Jest ona nienaruszalna, a jej poszanowanie i ochrona jest obowiązkiem władz publicznych". Stąd można wyprowadzić wniosek, że godność jest jakościowym wyznacznikiem bezpieczeństwa personalnego. Należy zatem zgodzić się ze stwierdzeniem, że człowiek w nowym paradygmacie powinien być postrzegany zgodnie z wizją personalistyczną. Zakłada ona nadrzędną wartość człowieka wobec uwarunkowań społeczno-ekonomicznych, podkreśla godność człowieka opartą na szacunku do osoby ludzkiej oraz stanowi jego prawo do wolności, prawdy, sprawiedliwości, poszanowania własności (Domański, Kotarba, Krupa, 2014). Godność człowieka jest atrybutem niezbywalnym i ma nadrzędne znaczenie w odniesieniu do praw i obowiązków wszystkich podmiotów bezpieczeństwa, których bezpieczeństwo wymaga obro- 
ny i ochrony. Ujęcie systemowe pozwala wskazać, że podmiotowe rozumienie bezpieczeństwa jest niewystarczające. Stąd elementem niezbędnym jest dodanie kryterium przedmiotowego do podmiotu bezpieczeństwa. W odniesieniu do bezpieczeństwa personalnego może to być nie tylko bezpieczeństwo praw i wolności, ale np. społeczne (egzystencji człowieka).

W systemie powstają różne rodzaje relacji. Pierwszym z nich są relacje jednokierunkowe, asymetryczne oraz stałe i wzajemne, które mają walor systemotwórczy. W ramach tego typu relacji jeden element jest nadawcą, a drugi adresatem jego działań (sprzężenie jednostronne). Bezpieczeństwo personalne zależy w głównej mierze od działań państwa (nadawcy), którego rolą jest zapewnienie bezpieczeństwa w wielu dziedzinach aktywności człowieka (adresata), np. ochrony przed przestępczością czy zagwarantowanie prawa do godnego życia. Ujęcie systemowe pozwala na ukształtowania nowego spojrzenia na bezpieczeństwo widzianego nie tylko z perspektywy wartości chronionych, ale szeregu innych elementów, które są ze sobą wzajemnie powiązane. Wprowadza się w ten sposób ogniwa (pojęcia) łączące rozmaite dyscypliny naukowe (nauki prawne, o polityce i administracji, psychologię itd.), a tym samym umożliwia się wspólne korzystanie z dorobku poszczególnych dyscyplin, co pozwala na szerszą analizę fenomenu bezpieczeństwa. Bezpieczeństwo personalne z pewnością musi uwzględniać nie tylko prawny, ale też biopsychospołeczny wymiar osoby ludzkiej.

System bezpieczeństwa personalnego, mimo indywidualnego zróżnicowania, odnosi się do potrzeb i wyznawanych wartości. Przyjmowane jest założenie, że „bytem substancjonalnym są jedynie osoby ludzkie tworzące społeczeństwo, ale społeczności ludzkie także istnieją realnie, są całościami różniącymi się od osób, które je tworzą" (Korzeniowski, 2008). Natomiast system można określić jako sposoby postępowania, jakie państwo podejmuje w swych działaniach dla zapewnienia bezpieczeństwa jednostce. Wejścia i wyjścia pozwalają na uchwycenie zjawisk związanych z wzajemnym oddziaływaniem systemu na bezpieczeństwo człowieka. Są nimi głównie oczekiwania co do pożądanego stanu bezpieczeństwa i poparcie tych oczekiwań (lub nie) przez państwo. System bezpieczeństwa odnosi się tutaj do konkretnego podmiotu, którym jest człowiek, ale też uwzględnia rolę państwa w kontekście zapewnienia bezpieczeństwa. Sprężenie zwrotne uwzględnia zachodzące interakcje pomiędzy podmiotami (ryc. 4). System ten utrzymywany jest w stanie dynamicznej równowagi dzięki różnego rodzajom instytucjom zaklasyfikowanym do systemu obronnego, ochronnego czy wsparcia (gospodarczego i społecznego).

Relacje między bezpieczeństwem państwa (najczęstszym sposobem myślenia o bezpieczeństwie) a bezpieczeństwem jednostki ludzkiej są różnie postrzegane. 
Z jednej strony oba wymieniane podmioty bezpieczeństwa są rozumiane jako alternatywne wobec siebie, $\mathrm{z}$ drugiej jako uzupełniające się. Te sprzeczne poglądy wynikają z odmienności podmiotów, ale nie oznaczają wykluczania się obu pojęć. W ujęciu systemowym są obszarami wobec siebie komplementarnymi. Przedstawiony poniżej model przedstawia wzajemne zależności pomiędzy tymi podmiotami (rama analityczna).

Metodą stosowaną w tym paradygmacie może być analiza systemowa. Celem analizy systemowej może być skonstruowanie modelu pojęciowego systemu bezpieczeństwa. Jest to całokształt zasad i metod naukowego myślenia oraz wszystkich środków pozwalających na badanie zespołu zjawisk dotyczących bezpieczeństwa w ujęciu całościowym. Analiza systemowa polega na tworzeniu modelu systemowego, który można nazwać modelem pojęciowym systemu bezpieczeństwa. Wyodrębniony problem bezpieczeństwa opisywany będzie jako integralna całość wyróżniająca się z otoczenia i wymagająca interwencji. Bezpieczeństwo personalne i strukturalne jest układem relacji oczekiwań jednostki ludzkiej (dotyczących potrzeb i ochrony wartości) i możliwości ich realizacji (ryc. 4). W ten sposób można rozróżnić podmiot bezpieczeństwa oraz obiekt (przedmiot) referencyjny (Wróblewski, 2017).

W tym przypadku podmiotem bezpieczeństwa pozostaje państwo (przyczyniające się do bezpieczeństwa człowieka), a obiektem referencyjnym, któremu należy zapewnić bezpieczeństwo, jest jednostka i społeczeństwo.

Ryc. 4. System bezpieczeństwa personalnego

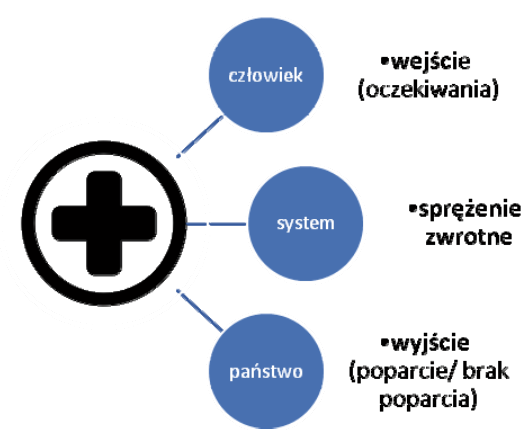

Źródło: opracowanie własne.

Na szczególną uwagę potwierdzającą współzależność podmiotów bezpieczeństwa zasługuje koncepcja human security, czyli bezpieczeństwa jednostki (osoby ludzkiej), która stała się kolejnym stadium koncepcji poszerzonego ujmowania 
bezpieczeństwa (Gierszewski, 2017b). Termin ten upowszechnił Raport Organizacji Narodów Zjednoczonych ds. Rozwoju (UNDP) z 1994 roku (United Nations Development Program, 1994). W Raporcie dokonano interpretacji bezpieczeństwa jednostki oraz związku pomiędzy zrównoważonym rozwojem a bezpieczeństwem. Autorzy raportu uznali, że zagadnienie bezpieczeństwa zbyt długo definiowano jako bezpieczeństwo terytorium wolnego od zewnętrznej agresji, jako ochronę narodowego interesu w polityce zagranicznej lub jako światowe bezpieczeństwo wolne od nuklearnego zagrożenia. Tymczasem dla większości ludzi brak poczucia bezpieczeństwa wynika z obawy o codzienny byt, a nie ze strachu przed światową katastrofą. W Raporcie wyróżniono dwa główne nurty koncepcji bezpieczeństwa personalnego. Pierwszy oznacza wolność od takich problemów jak głód, choroby i represje ze względu na pochodzenie, rasę, płeć, wyznanie czy poglądy polityczne. W drugim nurcie określa się bezpieczeństwo jako ochronę przed nagłymi i trudnymi wydarzeniami w życiu codziennym: w domu, w pracy czy też w społeczeństwie. Sedno analizowanego problemu to ujęcie istoty człowieka i zagrożeń bezpieczeństwa personalnego. Pozostałe rodzaje bezpieczeństwa i zagrożeń są jego rozszerzeniem i uszczegółowieniem (Kołodziejczyk, 2009). Koncepcja human security jest przykładem systemowym, gdyż polega na ujmowaniu bezpieczeństwa w kategoriach układów zintegrowanych relacji pomiędzy podmiotami bezpieczeństwa i jest dobrym przykładem na zastosowanie wielu paradygmatów. Paradygmat systemowy zakłada integralność całego systemu i postrzega bezpieczeństwo personalne jako system homeostatyczny równoważący przepływ pomocy udzielanej do oczekiwanej. $Z$ punktu widzenia epistemologicznego ten paradygmat zakłada obiektywny, przyczynowo-skutkowy charakter pomocy, neutralność aksjologiczną badań i badacza oraz tworzenie ogólnych, sformalizowanych obrazów bezpieczeństwa społecznego.

Sytuując bezpieczeństwo personalne w ujęciu systemowym, należy je rozpatrywać w kontekście bezpieczeństwa strukturalnego. Pryzmat „bezpieczeństwa” to identyfikowanie i zapobieganie różnym zagrożeniom, dlatego interpretować należy je w ujęciu podmiotowym oraz przedmiotowym (kryterium podmiotowo-przedmiotowe bezpieczeństwa). Podejście systemowe z uwagi aparat pojęciowy i stosowaną metodologię daje możliwość uporządkowania i uogólnienia różnorodności występujących koncepcji w naukach o bezpieczeństwie. 


\section{Zakończenie}

Podsumowując prezentowane rozważania, należy przyjąć, że jednym z kluczowych elementów budowy efektywnych modeli bezpieczeństwa podmiotu, które mają charakter trwały, jest oparcie na właściwych paradygmatach. Nie można tego zrobić na jednym paradygmacie, lecz zasadne jest wykorzystanie zasady wieloparadygmatyczności nauk o bezpieczeństwie. Trwają, może i bezskuteczne, poszukiwania, aby zastosować kategorię paradygmatu do tej dyscypliny naukowej. Może należałoby, w odróżnieniu od pierwotnego znaczenia, nie traktować paradygmatu jako wzorca, charakterystycznego dla danej, wąskiej dyscypliny, ale jako pojęcie opisujące całokształt poglądów przedstawicieli różnych dyscyplin naukowych zajmujących się problematyką bezpieczeństwa?

Punktem wyjścia może być rozpoznanie faktycznego stanu wiedzy, który pozwoliłby ustalić aktualne problemy badawcze. Obecnie nauki o bezpieczeństwie zapożyczają paradygmaty oraz instrumentaria metodologiczne z innych dyscyplin nauk społecznych, ale nie wiadomo, które z nich powinny mieć priorytet $\mathrm{w}$ badaniu bezpieczeństwa.

Za uprawnione należy uznać stwierdzenie o wieloparadygmatycznej strukturze nauk o bezpieczeństwie. Można mieć jednocześnie wątpliwość, czy jest to równoznaczne z uznaniem, że nauki te znajduje się rzeczywiście w stadium przedparadygmatycznym (co oznaczałoby przyjęcie, że osiągnięcie stanu paradygmatycznego może być niemożliwe).

Analiza koncepcji Th. Kuhna jako pewnej propozycji z dziedziny filozofii nauki, a następne odniesienie zrekonstruowanego przez niego modelu nauki do nauk o bezpieczeństwie uprawnia, jak się wydaje, do poczynienia kilku uwag.

Po pierwsze, problematyki bezpieczeństwa nie da się zamknąć w jednej dyscyplinie naukowej, a więc nadal będzie pod wpływem teorii formułowanych przez przedstawicieli różnych dyscyplin naukowych, co być może uniemożliwi przyjęcie jednego paradygmatu.

Po drugie, niezbędne w obrębie nauk o bezpieczeństwie wydaje się dokonanie wyboru postawy metodologicznej (warunków metodologicznego poznania), w którym nastąpi uszczegółowienie paradygmatów i umożliwione będzie dokonanie wyboru właściwych instrumentów badawczych.

Po trzecie, z uwagi na wieloznaczność istniejących koncepcji, bezpieczeństwo warto opisywać na gruncie wielu paradygmatów, które pełnią funkcję ukierunkowującą, inspirującą i konsolidującą środowisko badaczy.

Po czwarte, nauki o bezpieczeństwie opierają się na różnych paradygmatach, co znajduje swój wyraz w postawach badawczych oraz preferowanej metodyce opi- 
sującej i interpretującej fenomen bezpieczeństwa, a tym samym stwarzają szansę na obiektywność badań.

Po piąte, zadaniem nauk o bezpieczeństwie powinna być próba znalezienia bądź stworzenia modeli, które kompleksowo ujmowałyby problematykę bezpieczeństwa jako systemu zdolnego do przeciwstawienia się zagrożeniom militarnym i niemilitarnym.

\section{Bibiliografia:}

Czaja, J. (2008). Kulturowe czynniki bezpieczeństwa. Kraków: Krakowska Szkoła Wyższa im. Andrzeja Frycza Modrzewskiego.

Domański, J., Kotarba, W., Krupa, T., (2014). The Prisms of Management. Foundations of Management, 6.

Drabik, K. (2013). Bezpieczeństwo personalne i strukturalne. Warszawa: Akademia Obrony Narodowej.

Frankfort-Nachmias, C., Nachmias, D. (2001). Metody badawcze w naukach społecznych. Poznań: Wydawnictwo Zysk i S-ka.

Gierszewski, J. (2013). Model bezpieczeństwa społecznego na tle teorii systemów. Colloquium Wydziału Nauk Społecznych i Humanistycznych, 2.

Gierszewski, J. (2017a). Problemy tożsamości nauk o bezpieczeństwie jako dyscypliny społecznej. W: T. Kośmider, W. Kitler (red.). Granice tożsamości nauk o bezpieczeństwie. Perspektywa materialna i formalna. Warszawa: Difin.

Gierszewski, J. (2017b). Bezpieczeństwo społeczne w koncepcji human security. W: M. Chrabkowski, C. Tatarczuk, J. Tomaszewski, W. Wosek (red.). (2017). Bezpieczeństwo państwa we wspótczesnej Europie. Zagrożenia i przeciwdziatanie. Gdynia: WSAiB w Gdyni.

Gierszewski, J. (2018). Problemy tożsamości nauk o bezpieczeństwie w perspektywie subdyscyplin i nauk pomocniczych. Warszawa: Difin.

Glen, A. (2014). Model procesu poznania w naukach o bezpieczeństwie. Zeszyty Naukowe $A O N, 4(97)$.

Guba, E., Lincoln, Y. (1994). Competing Paradigms in Qualitative Research. W: N.K. Denzin, Y.S. Lincoln, Handbook of Qualitative Research. Sage: Thousand Oaks.

Gray, M. (2005). Archetypal Explorations: An Integrative Approach to Human Behavior. New York: Routledge.

Hołyst, B. (2014). Bezpieczeństwo. Ogólne problemy badawcze, t. 1. Warszawa: PWN.

Hofreiter, L. (2012). Wstęp do studiów bezpieczeństwa. Kraków: Of. Wyd AFM.

Hofreiter, L. (2013). Rozważania nad bezpieczeństwem. Securitologia, 1, 17-31.

Jurgilewicz, M., Sulowski, S. (red.). (2018). W kręgu nauki o bezpieczeństwie. Warszawa: Difin.

Kitler, W. (2011). Zarządzanie kryzysowe w Polsce, stan obecny i perspektywy. W: G. Sobolewski, D. Majchrzak (red.). Zarzadzanie kryzysowe w systemie bezpieczeństwa narodowego. Warszawa: Akademia Obrony Narodowej. 
Kitler, W. (2015). Transdyscyplinarność badań w naukach o bezpieczeństwie i obronności. W: T. Kośmider, W. Kitler (red.). Granice tożsamości nauk o bezpieczeństwie. Perspektywa materialna i formalna. Warszawa: Difin.

Kołodziejczyk, K. (2009). Bezpieczeństwo. Kontekst personalno-aksjologiczny. Zeszyty Nankowe WOSWL, 1 .

Kośmider, T., Kitler, W. (2017). (red.). Granice tożsamości nauk o bezpieczeństwie Perspektywa materialna i formalna. Warszawa: Difin.

Korzeniowski, L.F. (2012). Podstawy nauk o bezpieczeństwie. Zarzadzanie bezpieczeństwem. Warszawa: Difin.

Korzeniowski, L.F. (2008). Securitologia. Nauka o bezpieczeństwie człowieka i organizacji społecznych. Kraków: Wyd. EAS.

Korzeniowski, L.F. (2007). Securitologia na początku XXI wieku. Securitologia, 6, 181-192 .

Kuhn, Th.S. (2011). Struktura rewolucji naukowych, tłum. H. Ostromęcka. Warszawa: Fundacja Aletheia.

Piwowarski, J., Gierszewski, J. (2018). (red.). W poszukiwaniu tożsamości nauk o bezpieczeństwie. Warszawa: Difin.

Powszechna encyklopedia filozofii. (2007). Lublin: Towarzystwo Tomasza z Akwinu.

Sady, W. (2015). Rewolucje naukowe a problem obiektywności naukowej wiedzy. Zagadnienia Naukoznawstwa.

Sułkowski, Ł. (2009). Interpretative Approach in Management Sciences. Argumenta Oeconomica, 2.

Świniarski, J. (1997). O naturze bezpieczeństwa. Warszawa-Pruszków: ULMAK.

Wróblewski, R. (2017). Wprowadzenie do nauk o bezpieczeństwie. Siedlce: UP-H w Siedlcach.

Zięba, R. (2012). O tożsamości nauk o bezpieczeństwie. Zeszyty Naukowe AON. 